\title{
Tratamiento inicial de heridas por proyectil de arma de fuego. A propósito de un caso clínico
}

\author{
Initial treatment of gunshot wounds. A clinical case report
}

\author{
L. Ramos Xavier1, M. Alves Crespo2, C.M. Soares de Oliveira3, L. de Freitas Baldez ${ }^{4}$
}

Resumen: Los profesionales de salud en Rio de Janeiro tienen que perfeccionarse en un tema que cada vez más viene ganando espacio en los hospitales públicos de Río de Janeiro: la medicina de guerra.

En el área de la cirugía bucomaxilofacial la preocupación de estos profesionales está dirigida a la devolución de la estética y función facial, teniendo en vistas que, estas heridas causan daños de grandes proporciones. En este sentido, el servicio inicial al paciente herido por arma de fuego en la cara será determinante para el éxito del tratamiento de este tipo de trauma. Este trabajo pretende, desde el relato de un caso clínico, promover discusiones con otros profesionales actuantes en el área de atención al paciente víctima de PAF (proyectil de arma de fuego). El paciente objeto de este estudio fue víctima de un asalto, siendo herido por un proyectil que penetró por la región geniana y quedó alojado en la región cervical, presentando fractura fragmentada de rama ascendiente y proceso coronoide de la mandíbula. Debido a las controversias que hay en la literatura mundial sobre las conductas en esta atención precoz, proponemos este trabajo.

Palabras clave: Fractura facial; Tratamiento inicial; Herida por arma de fuego; Proyectil de arma de fuego).

Recibido: 26.10 .05

Aceptado: 04.02.08

$11^{\circ}$ Teniente Dentista de la Policía Militar del Estado de Río de Janeiro-Brasil. Residente do Servicio Cirugía e Traumatología Bucomaxilofacial de la Marina de Brasil. Investigadora del Departamento de Traumatología e Ortopedia da Universidad Federal do Río de Janeiro, Brasil.

2 Capitão-Tenente Cirurgião-Dentista da Marinha do Brasil. Staff do Serviço Cirurgia e Traumatología Bucomaxilofacial da Odontoclínica Central da Marinha, Brasil

3 Capitão-de-Corveta Cirurgião-Dentista da Marinha do Brasil. Staff do Serviço Cirurgia e Traumatología Bucomaxilofacial do Hospital Naval Marcílio Dias. Brasil

4 Capitão-de-Fragata Cirurgião-Dentista da Marinha do Brasil. Staff do Serviço Cirurgia e Traumatología Bucomaxilofacial do Hospital Naval Marcílio Dias, Brasil.

\section{Correspondencia:}

Larissa Ramos Xavier

Rua Anita Nilo Peçanha 10A

São Francisco Niterói, Río de Janeiro, Brasil

Cep: 24360-210

Email: larissarx@hotmail.com
Abstract: Health care professionals in Rio de Janeiro have to gain expertise in a specialty that is becoming increasingly important in the public hospitals of Rio de Janeiro: military medicine.

In the field of oromaxillofacial surgery, the concern of health care professionals is to restore facial aesthetics and function because these wounds cause major damage. In this sense, the initial care of patients with facial gunshot wounds determines the success of treatment this type of trauma. The authors' intention in this report of a clinical case is to stimulate discussion among other professionals involved in the care of patients who suffer gunshot wounds (GW). The patient studied here was an assault victim who was wounded by a bullet that entered the genial region and lodged in the cervical region. He had a fragmented fracture of the mandibular ascendant ramus and coronoid process. Motivated by the controversy reigning in the world literature regarding the initial response in these cases, we proposed the current study.

Key words: Facial fracture; Initial treatment; Firearm wound; Gunshot wound. 


\section{Introducción}

Río de Janeiro (Brasil) registró, en el año de 2002, la segunda más alta tasa de homicidios dolosos (intencionales) del país, por detrás de Espírito Santo. Un estudio de la ONG VivaRio muestra que de cada 13 víctimas asesinadas en 1995, una murió en confrontación con la policía. Otro dato espantoso es que el $61 \%$ de las víctimas de la policía fueron disparadas en la cabeza.

En esta región las heridas por arma de fuego son inflingidas por una variedad de armas, de las cuales las de mayor incidencia en Río de Janeiro son los revólveres (Colt MKIV, Smith y Wesson 9 MM, Colt 38) y los fusiles (AR15, Fal y, AK-47). En los revólveres 38 y 45 , el proyectil sale de cañón con una velocidad de $253 \mathrm{~m} / \mathrm{s}$ y $265 \mathrm{~m} / \mathrm{s}$ respectivamente, y el daño provocado en el cuerpo humano es de 3 veces su diámetro. Por otro lado, los fusiles AR-15 $(715 \mathrm{~m} / \mathrm{s})$ y Fal $(840 \mathrm{~m} / \mathrm{s})$ alcanzan una área 30 veces mayor que la del diámetro de la bala.

El tratamiento de esas heridas se dive en tres fases: inicial, intermedia y reconstructiva. El tratamiento inicial es llevado a cabo por el servicio de reanimación, con el objetivo de asegurar la vida del paciente.

Es de especial importancia en esta fase la desobstrucción de las vías aéreas, a través de la limpieza de la orofaringe e intubación por medio de la traqueotomía o de la cricotirotomía y el control de la hemorragia, en prevención del choque hipovolémico. Se recomienda en esta fase del tratamiento el uso de antibióticos y la inmunización antitetánica, debido a la naturaleza contaminada de la herida por PAF (proyectil de arma de fuego). Además, los tejidos blandos desvitalizados y secuestros óseos deben ser retirados por medio de debridación conservadora.

La evaluación neuroquirúrgica y oftalmológica debe preceder el tratamiento instituido por la especialidad oromaxilofacial.

En este contexto, este trabajo expondrá un caso clínico con la intención de promover discusiones, enfatizando la necesidad de establecer un protocolo para el tratamiento de pacientes con herida facial por arma de fuego.

\section{Caso Clínico}

Paciente de raza blanca, de 32 años, admitido para tratamiento de herida facial por arma de fuego en el Hospital General de Nueva Iguazú (Brasil). Relató haber sido víctima de tentativa de asalto de su automóvil.

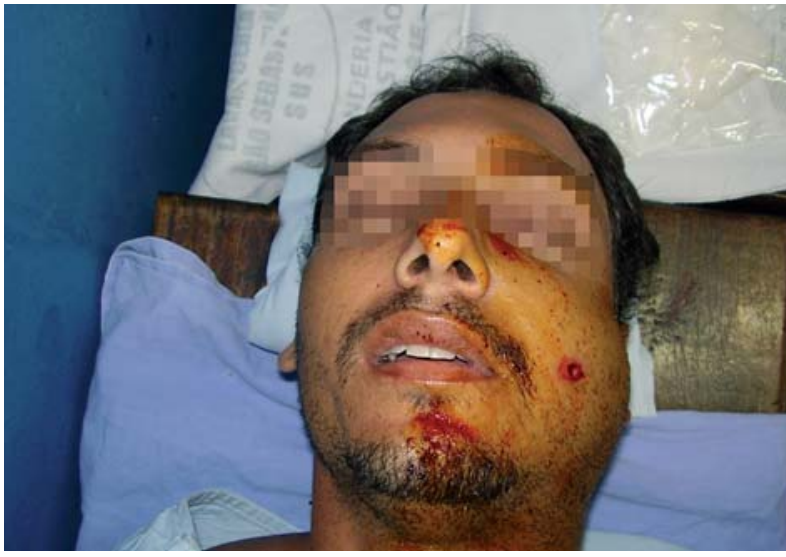

\section{Introduction}

Rio de Janeiro in 2002 had the second highest homicide rate in Brazil, after Espírito Santo. A study by the nongovernmental organization VivaRio shows that 1 out of every 13 victims assassinated in 1995 died in shoot-outs with the police. Another somber figure is that $61 \%$ of police victims had head wounds.

In this region, gunshot wounds are inflicted with a variety of firearms. The most frequent in Rio de Janeiro are revolvers (Colt MKIV, Smith and Wesson $9 \mathrm{~mm}$, Colt 38) and rifles (AR-15, Fal and, AK-47). In 38 and 45-mm revolvers, the bullet is expelled from the barrel at speeds of $253 \mathrm{~m} / \mathrm{s}$ and $265 \mathrm{~m} / \mathrm{s}$, respectively. The damage caused in the human body by the bullet is three times its diameter. In contrast, AR-15 $(715 \mathrm{~m} / \mathrm{s})$ and $\mathrm{Fal}(840 \mathrm{~m} / \mathrm{s})$ rifles affect an area 30 times greater than the bullet diameter.

The treatment of gunshot wounds is divided into three phases: initial, intermediate, and reconstructive. The initial treatment is carried out by the resuscitation service to save the patient's life.

Clearing airway obstruction by cleaning the oropharynx, intubation by tracheotomy or cricothyrotomy, control of bleeding, and the prevention of hypovolemic shock are of special importance in this phase. The use of antibiotics and antitetanic immunization is recommended in this phase of treatment because gunshot wounds are contaminated. In addition, devitalized soft tissue and sequestered bone must be removed by conservative debridement.

Neurosurgical and ophthalmologic evaluation are a prerequisite for specialized oromaxillofacial treatment.

Within this context, we report a clinical case with the aim of stimulating discussion, emphasizing the need to establish a protocol for treating patients with facial gunshot wounds.

\section{Clinical case}

A Caucasian patient, age 32 years, was admitted to Hospital General de Nueva Iguazú (Brasil) for the treatment of 
El paciente fue primero evaluado por la especialidad de neurocirugía, debido a la proximidad del proyectil a la columna cervical. Se encontraba consciente, hemodinámicamente estable, con las vías aéreas libres y demás datos del examen físico dentro de la normalidad. A continuación fue solicitada la evaluación del cirujano maxilofacial. En la exploración clínica, se identificó el orificio de entrada en la región geniana, midiendo $1 \mathrm{~cm}$ en su mayor diámetro, no habiendo orificio de salida (Figs. 1 y 2).

El paciente presentaba edema en la región geniana, mandibular y cervical izquierdas, con molestias álgicas. Fueron pedidas radiografías del macizo facial: (lateral oblícua de mandíbula, PA fronto-naso) y tomografía computadorizada.

En el examen radiográfico se observó fractura fragmentada de la rama ascendente mandibular. El proyectil permaneció alojado próximo a la columna cervical (Figs. 3, 4 y 5).

La pauta de medicación inicial fue: Keflin (antibiótico), dexametasona, profenid, dipirona y gammaglobulina.

El paciente fue ingresado en el Servicio de maxilofacial para ser operado de forma diferida (reconstrucción de la rama mandibular) después la regresión del edema.

\section{Discusión}

Río de Janeiro es el segundo estado brasileño en que más se muere por arma de fuego, despues del estado de Pernambuco (ONG VIVARIO, 2004).

Según investiga la ONG VIVARIO, la tasa de muertes por arma de fuego en el país casi se triplicó en los últimos 20 años. En el año de 2001 la tasa de muertes por 100 mil habitantes en Río fue del 39,7\%.

Datos de esta ONG afirman que en Brasil se muere más por arma de fuego $(29,6 \%)$ que por accidente de tráfico $(25,1 \%)$. Añade, todavía que, el arma de fuego mata más hombres jóvenes (15 a 24 años, 34\%) en Brasil que cualquiera otra causa combinada, sean enfermedades, accidentes de tráfico u otras causas externas.

Tosta (1990), estudiando un grupo de 400 pacientes atendidos en el Hospital Municipal Souza Aguiar-RJ (Brasil) verificó que el grupo de edad de mayor incidencia era de los 21 a los 40 años, pre-

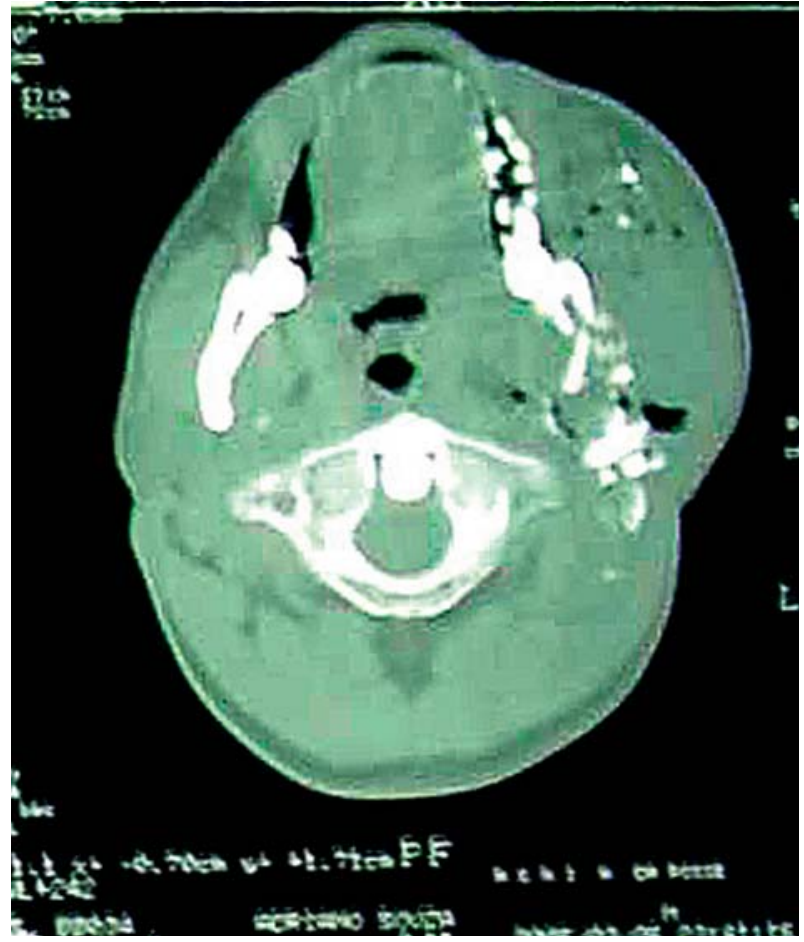

Figura 3. TC. Figure 3. TC.

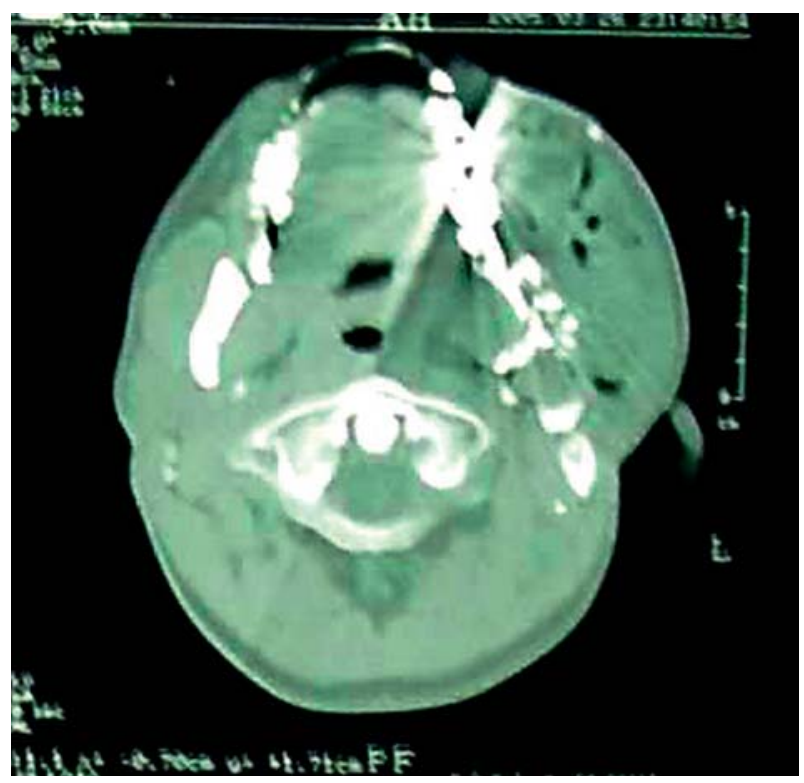

Figura 4. TC.

Figure 4. TC a facial wound caused by a firearm. He indicated that he had been a victim of an attempted car hijack.

The patient was evaluated first by the neurosurgery department because of the proximity of the bullet to the cervical spine. He was conscious, hemodynamically stable, and had clear airways and otherwise normal findings in the physical examination. Evaluation by the maxillofacial surgeon was requested. In the clinical examination, the diameter of the entry wound in the genial region was $1 \mathrm{~cm}$ at its widest and there was no exit wound (Figs. 1 and 2).

The patient had edema and pain of the left genial, mandibular, and cervical region. Radiographs of the maxillofacial region (oblique lateral mandible, posteroanterior frontal-nasal) and computed tomography were ordered.

The radiographic examination disclosed a fragmented fracture of the ascendant mandibular branch. The bullet was lodged against the cervical spine (Figs. 3, 4 and 5). The initial regimen of medications was Keflin (antibiotic), dexamethasone, profenid, dipyrone, and gammaglobulin.

The patient was admitted to the maxillofacial surgery department for deferred surgery (reconstruction of the mandibular ramus) after the edema had remitted.

\section{Discussion}

Rio de Janeiro is the second-ranked Brazilian state, after Pernambuco, in deaths due to firearms (VIVARIO, 2004).

According to the investigations of VIVARIO, the death rate due to firearms has almost tripled in Brazil in the last 
sentando 233 casos (58,25\%). Estos datos están de acuerdo con los referentes al paciente sujeto de este trabajo.

Cole (1994) relatan que en su casuística de 40 casos de heridas en la mandíbula y en la cara, el asalto responde al mayor número de casos $(62,5 \%)$.

Hay controversias en la literatura sobre la localización del orificio de entrada del PAF, sin embargo casi la totalidad de los autores estudiados relatan no haber observado orificio de salida del proyectil. (KHALIL, 1980, PRIETRO, 1995).

El paciente atendido en el Hospital Geral de Nova Iguaçu también tiene como causa del accidente una tentativa de hurto de su automóvil. La herida de entrada fue observada en la región geniana y el proyectil quedó alojado en las cercanías de la columna cervical, sin compromiso de esta. El paciente presentó fractura conminuta en la región de rama mandibular izquierda y esto está de acuerdo con estudios de Prietro (1995), Xavier, (2000), Tosta (1990). La mandíbula fue también fue citada como la hueso facial más fracturado en heridas por PAF en los trabajos de Phillips (1977), Tosta (1990) y Demetrides (1998).

Colombini y Silva (1986) preconizan como principio de tratamiento de las heridas por HAF (heridas por arma de fuego) normas básicas de urgencias aplicadas a los politraumatizados por la semejanza de la agresividad de estos traumas, resultando en grandes pérdidas volémicas, exigiendo, a su vez ligadura de arterias importantes, como la carótida externa, lingual y maxilar interna.

Describen como conducta de su Servicio el tratamiento quirúrgico en el primer tiempo, inmediatamente después el trauma, visando restaurar las condiciones del tejido blando, con especial atención en las HAF con comunicación bucocutánea.

Tienen como preocupación en unprimer momento, el controlar la hemorragia y la limpieza quirúrgica local, con el objetivo de lograr condiciones de aporte sanguíneo como soporte para un tratamiento ortopédico y neuroquirúgico eficaz. Son también realizadas en en este momento la inmovilización de los fragmentos óseos, bloqueo maxilo-mandibular, splints y otros medios convencionales. En los casos tratados por ellos, el procedimiento reconstructivo fue realizado en el período de 15 a 25 días de la lesión aguda. En

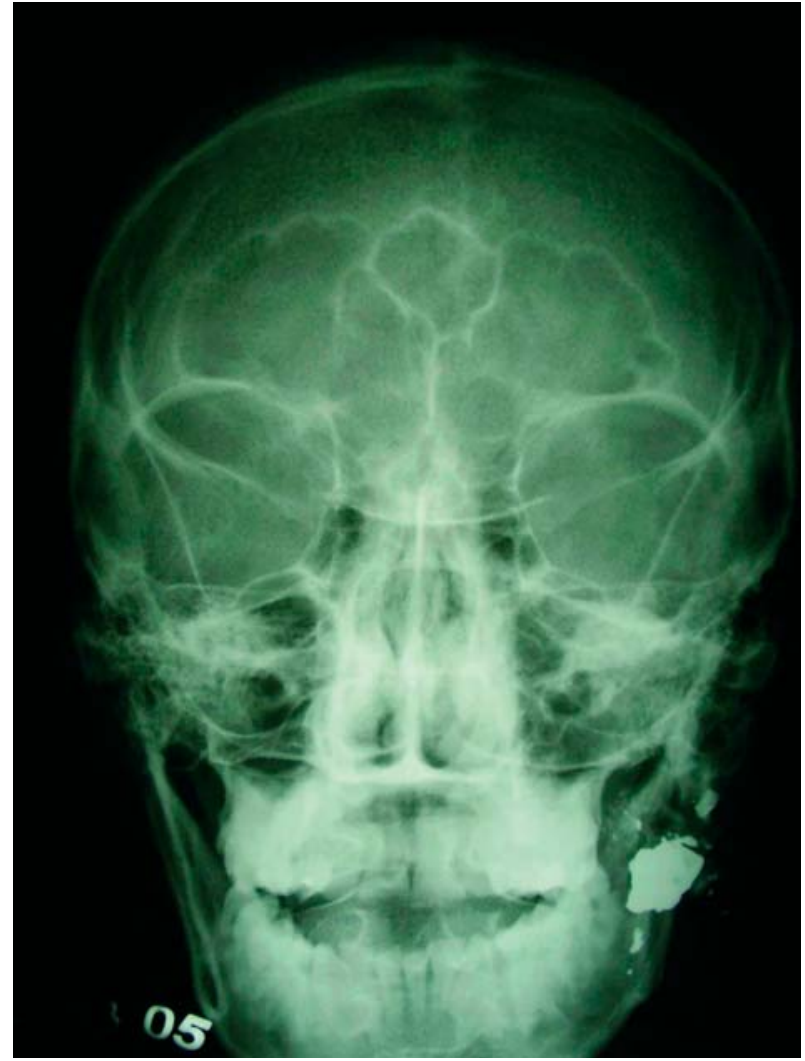

Figura 5. PA Rx.

Figure 5. $P A X R$.

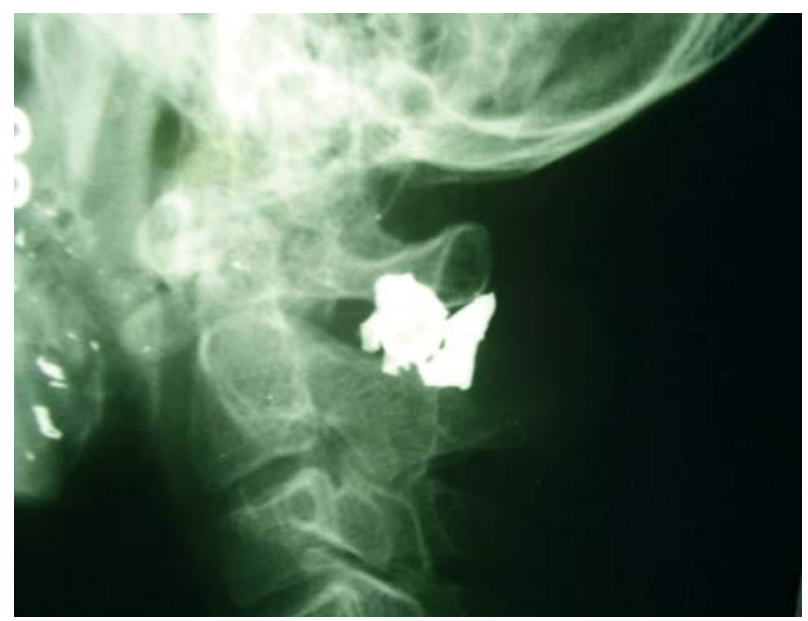

Figura 6. Lateral Rx. Figure 6. Lateral $x R$.
20 years. In 2001, the death rate per 100 thousand inhabitants of Rio was $39.7 \%$.

Figures from this NGO indicate that more people die from gunshot wounds (29.6\%) than by traffic accidents (25.1\%) in Brazil. In addition, firearms kill more young men (15 to 24 years, $34 \%$ ) in Brazil than all other causes combined, including disease, traffic accidents, and other external causes.

Tosta (1990), in a study of group of 400 patients attended by Hospital Municipal Souza Aguiar - RJ, found that the age group with the highest incidence was 21 to 40 years, with 233 cases (58.25\%). These figures concur with others related to the patient studied in the present paper.

Cole (1994) reports that, in a series of 40 cases of facial wounds, most were due to assault (62.5\%).

The location of the entry orifice in gunshot wounds is debated in the literature, but almost all the authors studied report that no exit wound is observed (KHALIL, 1980, PRIETRO, 1995).

In the case of the patient attended in Hospital Geral de Nova Iguaçu, the cause of the injury was also an attempted car hijack. The entrance wound was in the genial region and the bullet remained lodged near the cervical spine, but the spine was uninjured. The patient had a comminuted fracture of the left mandibular ramus, as described in the studies by Prietro (1995), Xavier, (2000), and Tosta (1990). The mandible is cited as the facial bone most often fractured in gunshot wounds in studies by Phillips (1977), Tosta (1990), and Demetrides (1998).

Colombini and Silva (1986) recommended the basic emergency measures applied to cases of multiple injuries as guidelines for the treatment of gunshot wounds. This was 
éste segundo momento los cuidados con antisepsia y antibioterapia son redoblados. En las lesiones nerviosas con pérdida de sustancia son realizados injertos libres, derivados del nervio auricular mayor.

Cardoso (2000), estudiando 27 casos de fracturas conminutas por PAF en la mandíbula en policías militares en São Paulo, constató que la mayoría de los casos fue tratado de forma conservadora (no quirúrgica, 69\%).

La revisión de las historias de pacientes víctimas de PAF en tres de los grandes hospitales de emergencia de la ciudad de Río de Janeiro, Xavier (2000), se observó que la resolución de los casos de fracturas mandibulares se dio de forma incruenta en la mayoría de los casos.

\section{Conclusiones}

Delante de las controversias existentes en la literatura a respecto del tratamiento del paciente víctima de proyectiles de arma de fuego, sugerimos como protocolo de servicio inicial al herido facial por arma de fuego, que sea evaluada la permeabilidad de las vías aéreas, control de la hemorragia y que el paciente sea estabilizado hemodinámicamente. Se debe proceder a la debridación conservadora de la heridas, analgesia, antibioterapia y profilaxis antitetánica.

Las heridas del tejido blando deben ser suturadas siempre que sea posible y las fracturas de los huesos faciales deben ser estabilizadas de preferencia con fijación interna rígida o con fijación semi-rígida, siempre que haya cobertura suficiente de tejido blando, con o sin bloqueo maxilo-mandibular. Los espacios referentes a los gaps de los huesos deben ser mantenidos por medio de placas de reconstrucción, para posterior injerto óseo y devolución de la forma y función facial.

\section{Bibliografía}

1. Alper M, Totan S, Çankayali R, Songür e. Gunshot wounds of the face in attempted suicide patients. J Oral Maxillofac Surg 1998;56:930-934.

2. Cardoso R. Fraturas cominutivas causadas por projéteis de baixa velocidade: análise de 27 casos tratados em SP, 2000 [Dissertação de mestrado- Faculdade de Odontologia da USP].

3. Chamber G, Scully C. Mandibular fractures in India during the second world war (1944 and 1945): Analysis of the snawdon series. B J Oral Maxillofac Surg 1997;25:357-69.

4. Cole R, Browne JD, Phipps CD. Gunshot wounds to the mandible and midface: Evaluation, treatment, and avoidance of complications. Otolaryngol Head Neck Surg 1994;111:739-45.

5. Colombini NEP, Silva EC. Novos conceitos no tratamento das fraturas faciais por projéteis de arma de fogo. Revista Odontólogo Moderno 1986;13:29-36.

6. Fonseca RJ, Walker RV. Oral and Maxillofacial Trauma 1994;948-81.

7. Goldman RS, Marcone C, Hansen NS, Infante VP, Romeiro RL. Protocolo para atendimento cirúrgico a pacientes vítimas de ferimentos por arma de fogo com perda de substância em mandíbula. Revista da EAP/APCD 2005.

8. Demetriades D, Chahwan S, Gomes H, Falabella A, Velmahos G, Yamashita D. Initial evaluation and management of gunshot wounds to the face. I Trauma 1998;45:39-41. because of similarities in the aggressiveness of the trauma, which produces large volume losses that require the ligature of important arteries, like the external carotid, lingual, and internal maxillary arteries.

They describe how their department conducts the initial surgical treatment, which takes place immediately after trauma occurs, to restore the soft tissue conditions. Gunshot wounds that produce a communication between the mouth and skin receive special attention.

Their concern in the first moment is to control bleeding and ensure local surgical cleaning with the aim of ensuring an adequate blood supply as a necessary condition for effective orthopedic and neurosurgical measures. At this time, bone fragments are immobilized, the maxilla and mandible are blocked, and splints and other conventional tools are used. In cases treated by them, the reconstructive procedure was performed in the 15 to 25-day period after the acute injury. In this second intervention, antiseptic and antibiotic measures are even stricter. In the case of nerve injuries with loss of tissue, free grafts of the major auricular nerve are made.

Cardoso (2000), in a study of 27 cases of comminuted fractures due to gunshot wounds in the jaw of military policemen in São Paulo, found that most cases are treated conservatively (69\% without surgery).

In a review of the records of patients who suffered gunshot wounds in three of the large emergency hospitals of the city of Rio de Janeiro, Xavier (2000) observed that mandibular fracture occurred without open wounds in most cases.

\section{Conclusions}

In view of the controversy reigning in the literature with regard to the treatment of victims of gunshot wounds, we recommend the evaluation of airway patency, control of bleeding, and hemodynamic stabilization of the patient the initial protocol of action in the case of facial gunshot wounds. Conservative wound debridement should be performed and analgesia, antibiotic therapy, and antitetanic prophylaxis should be given.

Soft tissue wounds must be sutured whenever possible and fractures of the facial bones have to be stabilized, preferably by rigid internal fixation or semi-rigid fixation, whenever sufficient soft tissue cover is available. The maxilla and mandible are blocked as necessary. Gaps in bones must be maintained using reconstruction plates and then filled later with bone grafts to restore facial form and function. 
9. Hollier L, Grantcbarova EP, Kattasb M. Facial Gunshot wounds: A 4 year experience. J Oral Maxillofac Surg 2001;59:277-82.

10. Kenefick TC. Gunshot wounds to the head and neck. / Laryngol Oto$\log 1976 ; 90: 335-45$.

11. Khalil AF. Civilian gunshot injuries to the face and jaws. B J Oral Surg 1980;18:205-11.

12. Kwapis BW. Early Management of maxillofacial war injuries. J Oral Surg 1954 October.

13. Phillips JG.: Plastic bullet injury: A case report. B / Oral Surg 1977;14: 199-202.
14. Prietro MS. Fernández JMT, Medlich MAM. Lesiones mandibulares y arma de fuego. Revista ADM 1995;LII:99-102.

15. Taher AAY. Management of weapon injuries to the craniofacial skeleton. J Craniofac Surg1998;9:371-82.

16. Tosta C. Fraturas faciais por arma de fogo na cidade do Rio de Janeiro, 1990 [Dissertação de mestrado- Faculdade de Odontologia da UFR]].

17. Xavier LR. Incidência e tratamento inicial das fraturas mandibulares por arma de fogo na cidade do Rio de Janeiro. Rev da Faculdade de Odontologia de Bauru/ USP 2000;8(1/2). 